\title{
The Research to Remove Barriers Between China and Tunisia in the Shipping Field
}

\author{
Donia Damak ${ }^{1}$ \\ ${ }^{1}$ Business Management Department, Donghua Unversity, China \\ Correspondence: Donia Damak, Business Management Department, Donghua Unversity, China. E-mail: \\ damak.donia@yahoo.fr
}

Received: January 22, 2018

Accepted: February 26, 2018

Online Published: March 14, 2018

doi:10.5539/ibr.v11n5p28

URL: https://doi.org/10.5539/ibr.v11n5p28

\begin{abstract}
Over the years, the trade from China to Mediterranean countries has boomed spectacularly. The fast development of foreign trade has not only pushed China's port industry and international shipping industry forward considerably, but also provided foreign ocean carriers and terminals opportunities and challengers. As Tunisia is a strategic location, the Tunisian ports overall goals are to increase the number of calls made to it. Then the market study between Mainland China and Tunisia turned to be necessary and meaningful.

The objective of this research project is as a first a theoretical review to introduce and describe collaborative logistics management and investigate its consequence on the supply chain. This purpose necessitates a framework to support the collaboration between the entities in the chain especially in terms of logistics activities. Despite the identified needs and potential benefits, there are still barriers, which must be identified to attain desired benefits.

On a second part the purpose of this study is to analyze China's port industry and ocean shipping market in a relation to trade with Tunisia and to recommend some suitable Chinese ports to cooperate with Tunisian ports and find the reason why some top shipping companies are still not carrying goods to Tunisia. Two market surveys are performed, one for finding suitable Chinese ports for the Tunisian ports to cooperate with, and one to collect information from several top shipping companies using the Tunisian ports.

In the third and last part a small research study focuses in the costs and quality shipment from China to Tunisia showing Tunisia as a transshipment port for the whole Maghreb. The case of study will be a proof of future consideration for Chinese shipping companies to assure a direct shipping line to the port of Tunisia. The case of study will be affirmed by statistical and theoretical analysis in order to confirm the idea.
\end{abstract}

Keywords: collaboration, Chinese ports, shipping industry, Tunisia ports, transshipment port

\section{Introduction}

Since 1978 the real growth of GDP of China has averaged 9.3\% per year. The robust GDP growth has helped trade. China's membership of the World Trade Organization (WTO) since November 2001 has also contributed in the country's economic development. China has become the origin of most supply chain in the world economy, a world production base and an attractive consumption market. The past two decades have seen China's amazing development in foreign trade. (Coyle, J.J., Bardi, E.J. \& Novack, R.A., 2006)

Through much market research I can conclude that the traffic going in and out of China is growing up. However this development is not yet observed in the Mediterranean Zone although the Mediterranean offers great potential for liner shipping especially Tunisia which is ideally located along some of the world's major Shipping routes.

On the basis of equality and mutual benefit, China has long pushed for expanded economic and trade cooperation with the African countries, especially since the founding of New China and the African countries' success in gaining national independence. A new-type strategic partnership, based on mutual political trust, economic reciprocity and mutual cooperation, has been established between the two under common effort.

Based on the purpose of the study, the research will focus on logistics as a part of supply chain management and investigate the collaborative logistics management considering the driving forces, benefits, and barriers to 
effective logistics collaboration. This study will have both theoretical and practical relevance. While most of the research will be written based on the theoretical perspective, the final purpose of the research will be fulfilled practically through some statistics analysis, graphs and cost analysis of some of the main shipping lines handling containers to the Mediterranean sea.

The overall aim of this thesis is to make a study of China's port industry and shipping market in a relation trade with Tunisia. Two market surveys will be performed: one is related to using the Tunisian ports among several top shipping companies why the traffic between China and Tunisia is still low; the other is to find out the advantage of Tunisian port as becoming a transshipment port.

\section{Methodology}

- Study the shipping industry in China and Tunisia;

- To understand the trend for both countries;

- Finding causes and barriers existing between the cooperation of Tunisia and China in the shipping filed;

- Find the way to remove those barriers by reasons supporting: case of study will be performed.

\section{The Shipping Industry in China}

At the beginning of the reform and opening, China's ports were apparently in lack of capacity and the port berths were always congested, which had restricted the development of the national economy and foreign trade, especially in 1980's. Since the middle 1990's, the congestion of port berths has been alleviated.

China's container transport started in the seventies; it developed rapidly from the eighties. As the container vessels grow larger and larger, the main coastal ports in China began to construct the dedicated container berths. And those container berths are mainly built in Shanghai, Tianjin, Dalian, Qingdao, Ningbo, Xiamen, Shenzhen, and Guangzhou port. China invested heavily in the port construction, and the foreign capital was permitted to invest in port project. Since the middle of eighties, the port of Shanghai, Tianjin, Dalian, Qingdao, and Guangzhou began their international regular cargo ship lines. Until 1997, there are 30 ports in China that have developed the international container transport lines. (Branch A.E., 2003).

The number of containers handled by Chinese ports has maintained an annual growth rate of 30 percent in the past decade. In 2005, the number of containers handled by Chinese ports amounted to 37 million TEUs (domestic and international), about 30 times the volume of 1989. In 2005, the container throughput in main coastal ports won a $36.9 \%$ increase compared to 2004. The international container throughput reached 33.8 million TEUs in 2006, while the throughput of top eight ports (Shanghai, Shenzhen, Qingdao, Tianjin, Guangzhou, Ningbo, Xiamen, and Dalian) accounted for 29.17 million TEUs, taking $86 \%$ of the total volume. (www.zgjtb.com)

In 2008, the cargo throughput of China's major coastal port reached 3 billion tons with the annual growth rate of 7\%; the container throughput reached 100 million TEUs. (The 2009 Report on China's Shipping Development)

Although the international shipping industry began at a rather late stage and from a low level, it has grown remarkably and become a new growth point for China's fast-developing economy. Latest statistics show China's total foreign trade volume last year surged $21.8 \%$, reaching US $\$ 620 \mathrm{bn}$, among which exports rose $22.3 \%$ and imports $20.5 \%$, the overall shipping tonnage kept an increase about $8-10 \%$ every year. The Chinese international maritime transportation trade increased by $14 \%$ in 2007 to $736 \mathrm{~m}$ tons, of which imports were up by $16 \%$ to $416 \mathrm{~m}$ tons while exports were up $13 \%$ to $320 \mathrm{~m}$ tons.

China's shipping now ranks the fifth largest in the world with 50 million tons of handling capacity in operation -37 million tons in foreign trade. The following factors can be concluded as the dominant drivers for overall growth in the Chinese international shipping industry. (www.chinadaily.com.cn)

- Organic growth, where China is taking market share from other Asian locations, because of its overall competitiveness. The relocation of Japanese, South Korean and Taiwanese manufacturers is good examples.

- The enormous speed of China's economic growth is the real powerhouse for the industry.

- The alteration in the way of transport: the containerization of bulk cargo.

- The shift in transport mode from Hong Kong to South China. Because of the simple fact that it will help the shipper to reduce the transport cost greatly by shipping the goods via the mainland seaports in South China. 
The significance of China's shipping is growing and the nation will continue to play a big role in the global industry, especially now that it is a member of the WTO. Since $90 \%$ of China's foreign trade volume is shipped out by sea, experts agree that, with the increase of imports and exports. China seaborne foreign trade volume is expected to increase by eight percent to ten percent, from 393 million tons in 1998 to 656 million tons in 2007. But to meet the challenges from foreign counterparts, China's shipping industry still has a long way to go. (Imms M, Ereaut G, 2005)

\subsection{The Developing Trend}

Economic globalization will exert significant influence on world economy as well as on world shipping, which is oriented towards openness. The development of multinationals in turn contributes to the health and well being of world shipping. What is required of shipping corporations is to expand cross-border operation through mergers and acquisitions and to provide global shipping services. China's shipping is becoming an important link in the chain of global shipping. Liner carriers of China can launch mergers and acquisitions on a larger scale and can develop third or even fourth party logistics business. Foreign liner shipping companies will not be subject to any restrictions to set up subsidiaries in China, and they can well penetrate the Chinese market with their asset and technological advantages. (People's Republic of China Yearbook, PRC Yearbook, Beijing, 2008)

Analysis by officials of the Ministry of Communications indicates that China's international shipping industries will see the following development trends:

1. The opening of Chinese shipping market will be deepened and accelerated while more foreign capital will be allowed to enter into this market. Parts of the field inaccessible for foreign investment in the past will be gradually opened in the future, for example distribution service, international shipping agency and setting-up branches of foreign shipping companies in China.

2. The institutionalization process of the shipping market will be expedited. In case that the combination of Chinese shipping market with the world market will be promoted by the joining of foreign capital, China must step up the market institutionalization to impose supervision on the market entry and market behaviour of foreign companies in accordance with the Chinese laws and regulations

3. Chinese shipping companies will enjoy a better environment in the competition of world market. In the face of the increasingly fierce competition, some of the Chinese shipping companies will have to tap for new markets, such as to ship goods for a third party in order to optimize China's international shipping structure. Furthermore, China will be able to enjoy more initiative rights in international talks for shipping business. As foreign companies will get more benefit from the Chinese market after getting their entry permission.

4. Demand for shipping will be increased along with the growth of international trade volume. With China's entry into the WTO, the domestic market will be further opened with the international environment for foreign trade improved. China will by then has more to do in the work division of the world economy with the Chinese economy depending more on the world market at the same time. All these changes will by and large promote the development of the Chinese industries with comparative advantages and help raise greatly the transport volume in international trade, thereby boosting the development of the Chinese shipping industry.

In 2006, the container throughput of all the top ten ports reached 22.37 million TEUs; the ratio of container to the whole throughput has been raised by $1.5 \%$ compared to that in year 2005 . The development of large ships brings about the reduction of the corresponding ports for mooring the ship. This trend also leads to the centralization of ports: few ports that have leading edge in hardware will become the key container ports. (Kinnear, T. C., Taylor, J. R., 2007).

From January to July 2008, container volume handled by China's major ports amounted to 25.67 million TEUs, up $31.8 \%$ over the same period last year, according to China's Ministry of Communications. Shanghai maintained its leading position with growth of 35.6 percent to 6.18 million TEUs. Ningbo remained the fastest growing container port among the top 10 with a $53.6 \%$.

\subsection{Leader's Company Profile}

\subsubsection{COSCO Line}

As the first international shipping company of the People's Republic of China, the China Ocean Shipping Company (COSCO) was founded on April 27, 1961. COSCO owns one of the largest fleets in the world. Owned 
by the state, it is a diversified group whose main business is international shipping. The group has now grown mainly in the fields of shipping agency, freight forwarding, marine bunker supply, road transport, air freight transport, terminal operations, manufacturing, trade, real estate and tourism. It is one of the 56 big groups of enterprises approved by the State. (Beddow M, 2005)

COSCO develops remarkably over past 4 decades as the main line of business. At present, its asset is over 20 billion U.S. Dollars. The group achieved excellent performance in the first six months of 2010 . The total seaborne trade volumes during this period recorded up to more than 200 million tons, accounting for $66 \%$ over the planned figure. The group also carried out $61.1 \%$ of its ration on road transportation sector and $55.5 \%$ of its air cargo transportation plan respectively.

COSCON has grown rapidly in the past decade; it has woven a huge global service network consisting of more than 1000 agencies, spanning almost all of the global transport hubs. Overall its shipping schedule accuracy has consistently been $95 \%$ or higher since 1998. In particular, its US trade and Australia trade have maintained $100 \%$ schedule accuracy, becoming key features of the company's trading services. The company has been expanding its liner service routes into a new area. The expansion is aimed at integrating its global network of container transportation to enhance its competitiveness in the world market.

The company has the largest market coverage amongst the Chinese ocean carriers; it offers traditionally reliable and efficient container transportation with modern full-container ships. The high transport capacity makes the company one of the strongest providers on its connection, and most of liner service is popular with customers for quick and punctual delivery. It is very much committed to intra-Asian services; feeder vessels carry the goods from and to virtually every port in the Asian region.

COSCO states its mission as: "To be a world leader in shipping and logistics service by maintaining trustworthy relationships with our customers, employees and partners, yielding best returns for shareholders, society and environment."

The group is staying in the process of implementing an aggressive strategy, which mainly focuses on quality, cost-efficiency, IT and logistics. It is revealed that COSCO is aiming to further enhance its overall competitiveness in the international shipping industry, gradually broadening logistics-service activities, optimizing its organizational structure and making better use of its global shipping and logistics resources. To be more specific, the group's strategy will be explained in the following aspects. (Gao, 2008)

COSCO consider that it has the best range of services, which is very important for the group. The group has good reputation in the international market, it possesses of stable customers and market share. It also enjoys the advantages of rapid expansion. The on-going fleets have been increased and renewed. It has established its huge and mature logistics network in China, which can offer value-added service and gain the competitive advantages when competing with its main competitors. The group has established an Asia Pacific and European information network, an integrated regional information system, which will help it make better use of its resources and become more competitive. (K. H. Kim, Park, Y.M., Ryu, K.-R., , 2000)

The group has a strong financial base. It is one of the Chinese companies that have entered the global capital market according to international regulations.

As an international shipping company, $\mathrm{COSCO}$ will continue to contribute to shipping both inside and outside China, especially after China's accession to WTO. COSCON is planning a major restructuring intended to place it among the world's top three shipping lines. The company will enhance its co- operation with foreign cargo shippers, which should lead to lower freight costs and better services. It also tries to improve its after-sales service, currently a weak point. By improving service standard and promoting market competitiveness, the group is confident that it will become a world first-class shipping concern.

\subsubsection{China Shipping}

China Shipping Group was founded on July 1, 1997 in Shanghai. It is one of the big state-owned enterprises under the direct administration of the Central Government. China Shipping has established more than 30 overseas subsidiaries. There is five specialized shipping fleets in the group: oil tankers, tramps, passenger ships, container vessels and special cargo ships. It also operates the diversified businesses of integrated logistics, terminal management, finance and investment, engineering and labour service, trading, and information technology.

China Shipping Container Lines (CSCL) is the key company specializing in container transport under China Shipping Group. The company offers other relative services as well, such as storage, transshipment, and customs clearance. CSCL ranks among the world's 20 largest container carriers. The group's income of 2005 reached 27 billion Yuan, with a profit of more than 2.5 billion Yuan, among of container business accounts more than 50 percent. 
The group also succeeded in winning heavy support from the banks in China. China Shipping signed an agreement with China Bank this year in shanghai, it has received a 10 billion Yuan (US\$1.21 billion) credit line from China Bank to upgrade its fleet and enhance its competitiveness in the international shipping industry. (Guangdong Statistical Yearbook, 2006)

To become a world first class shipping company, the group is taking an active part in the terminal business at home and abroad. It has set up several joint ventures container terminal companies in coastal ports such as Dalian, Lianyungang, Shanghai and Zhanjiang. China Shipping signed the lease agreement for pier 100 and 102 at Los Angeles in the United States for a period of 25 years. The first berth of over 350 meters long and the container yard of 75 acres constructed in the first stage were put into use at the end of 2004.

The group developed its container terminal businesses actively in North America, Mediterranean, Europe, Southeast Asia by various ways such as share holding, share cooperation, long term lease etc.; meantime it found more partners along the coast of the mainland China, enhance the development of container terminal along the coast of south China, east China and north China, and expanded the coverage of China Shipping terminal business. The group's terminal business at home and abroad achieved a certain scale; the throughput reached 3 million TEUS. (www.people.com.cn)

In the past, the main fleets of China Shipping were bulk carrier and oil tanker; however, in recent two years the container fleets have reached rapid growth. Its domestic coastal transportation covers 11 ports from South China to North China, providing most economical, efficient and rapid service to the customer. Based on this advantage, China Shipping is trending to enhance the development of international shipping.

CSCL has kept expanding its shipping lines in the past four years. Currently, its service has already expanded to Australia, Europe, Japan, Mediterranean, North America, and South-West Africa. There are more than 30 foreign trade line connecting 75 ports in 20 countries. The company owns the most shipping lines and also the largest shipping capacity from Europe and the Mediterranean to Mainland China. (M. Grunow, H.-O. Günther, and M. Lehmann, 2006)

China Shipping has a big plan in expanding its fleet's capacity. The group and CMA-CGM has jointly ordered 5 by far the biggest container vessels in the world with capability of 9180 TEUs. These vessels were delivered in 2004 and used in American Line jointly. The group owns three of these vessels. By using giant container vessels, the cost of every container decreased because of the economy of scale. Experts predicted that the group got more competitive power and higher profit.

CSCL have the long-stated ambition of becoming a world top five container carriers in capacity terms. The company plans to expand continuously its worldwide liner services and provide more value-added service to customer.

CSCL's coastal service in the domestic trade has always been the market leader. Its foreign trade services have been stable and sure. Especially, the company has put the largest capacity in Euro-Mediterranean service. It reduced the frequency of its recently introduced trans-Pacific service from weekly to fortnightly in October 2008 , on what it called a temporary basis. The move is due to an expected downturn in volumes in the slack season post-Chinese New Year. But it is also being seen as a possible indication that the China/Europe trade offers more market potential for the company. (C. Carrascosa, M. Rebollo, J. Vicente, and V. Botti, 2009).

China Shipping is widely regarded as the most ambitious Chinese maritime player. According to the report of the group, by the end of 2012 the carrying capacity will be expanded beyond 30 million tons, container capacity will reach 520,000 TEUs. Its main ocean fleet will consist of 70 ships and an average space for container capacity of 7200 TEUs. With the advanced equipment, high technology and good management, the group will surely lead to a bright future, and achieve its goal as one of leading carriers in the shipping industry. (I. F. A. Vis, R. de Koster, 2010).

\section{The Shipping Industry in Tunisia}

Situated in the middle of the Mediterranean region, between a European market marked by a rapid economic development and an African continent boosted by its emergent economy and its market of hundreds of millions of inhabitants, the Tunisian ports are the most recommended sites for a competitive, reliable and secured transit of goods and ships.

The Tunisian port chain is composed of 7 ports open to international trade. It spreads over a coast of $1300 \mathrm{~km}$. The diversity of activities of these ports, their complementarities and their exceptional situation allow them to receive all types of ships and to handle all sorts of goods. 


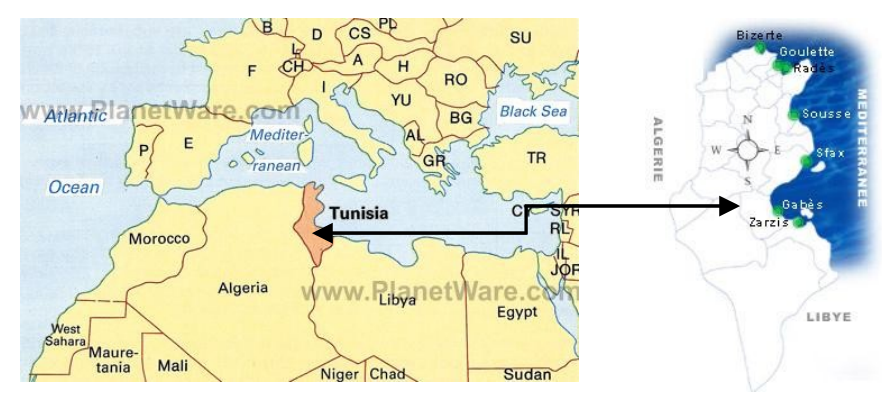

Figure 1. Map of Tunisia

The Tunisian economy is characterized by an increasing openness of the structure of production and exchange, which places foreign trade at the heart of its development issue and implies special attention to the transport sector, including shipping.

The importance of maritime transport sector in Tunisia is not to prove, it is exactly like other countries of the Maghreb. It is an essential service in foreign trade, an important vector of development, since it provides about 95\% of trade. (Port of Tunisia, Annual Report 2008)

Maritime trade is assured by 7 commercial ports: Bizerte Menzel Bourguiba, Tunis Gouolette Rades- which is the port complex in the capital-, Sousse, Sfax, Gabes, Zarzis and the oil port of Skhira. The Office of Shipping and Ports (OMMP) manage all ports, except the port of Skhira, which is managed by an oil company. The ports ensures the transit of about 26 million tons of cargo in 2000 composed of $39 \%$ hydrocarbons, $23 \%$ of bulk solids, $18.5 \%$ of general commodity, 11.5 of cereal and 8 bulk liquids. (Journal d'Afrique, Mai 2006).

It is important to note, firstly, that commercial activity in the Mediterranean and the Black Sea has the potential to play a major role for liner shipping companies. A number of important EU countries with highly developed markets border onto the Mediterranean, and numerous countries both in the Eastern and Western Mediterranean that is likely to undergo considerable development in the future.

Within advanced economies there is a direct relation between growth of GDP and long-term growth in quantity of containers. But in countries with a slower rate of growth there is an overall lower development of trade, as well as a lower proportion of goods transported in containers as compared to break-bulk goods (in other words, the opposite of advanced countries). If we divide the Mediterranean into an Eastern and Western sector, we note that containerization is much more developed in the western than in the eastern sector; the same is true of the northern as compared to the southern Mediterranean coastline.

The main difficulties faced by North African Mediterranean countries, which are non-EU countries, are the need for investment and for greater political stability and employment. Productivity is low in North African countries; their economies are mainly linked to agriculture, which accounts for almost $20 \%$ of their output.

The EU seeks to establish good contacts with these countries, and it is likely that the desired Euro-Mediterranean agreements with the EU could favor foreign investments both in human capital and physical assets. This would in turn help to develop intra-regional exchanges within the Mediterranean basin.

At present, however, the countries bordering onto the Southern Mediterranean coast remain weak, for the following reasons:

- Lack of direct foreign investment

- Lack of portfolio investment

Finally, their political instability introduces an element of uncertainty into the plans for economic reform in southern Mediterranean countries, and makes investment less attractive to foreign companies. 


\subsection{Overview of the Traffic of Goods per Products and Continents}
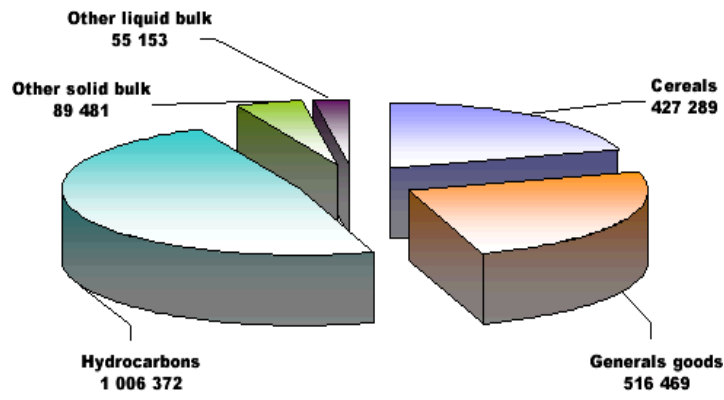

Figure 2. Distribution of the traffic of goods in the first semester 2010 (tons)

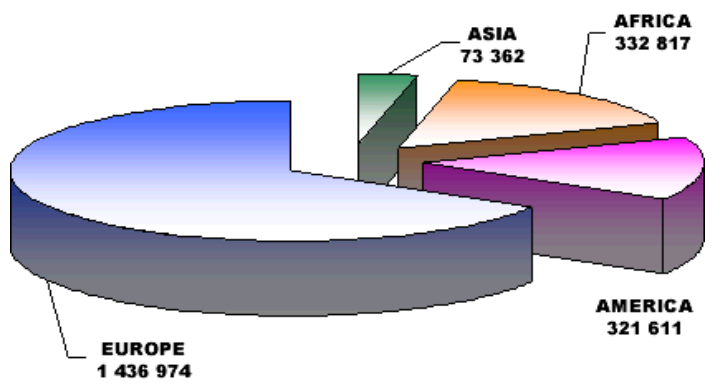

Figure 3. Distribution of the traffic of goods in the first semester 2010 (tons)

From Figure 2 and 3 we can notice that the ports of Bizerte main product distributers are the hydrocarbons and cereals shipped mostly to Europe.

Asian market is not noticeable here since there is no direct shipment service to Asia and most of the goods go through Europe, which has many transshipment ports.

\section{Reason to Remove the Barriers Between China and Tunisia in the Shipping Filed}

\subsection{The Developing Trend: China and Tunisia Relationship}

\subsubsection{Political Relation}

China established diplomatic relationship with Tunisia on January 10, 1964. The friendly cooperative relationship between the two countries in all fields is developing steadily. Tunisia attaches importance to the relationship with China, follows China's reform and open policy with interest, maintains high- level visits and other exchanges and develops cooperative partnership with China. Tunisia shares common views with China on many important international issues, and the two countries cooperate and support each other in international affairs. The Foreign Ministries of the two countries set up the periodical political consultation mechanism in December 1996. (www.Tunisia.tn; the port of Tunisia).

\subsubsection{Trade Relation}

Bilateral trade has been developing steadily. China has provided certain amount of economic aid to Tunisia since 1959. The volume of trade between China and Tunisia in 2005 was US $\$ 109,380,000$. China mainly exports tea and light industrial products while imports phosphate fertilizer. From 1984, Chinese companies of labour service entered Tunisia, involving them in the infrastructure building, agriculture, light industry and other related fields.

On the economic front, relations between the two countries are on track. They continue to strengthen. As such, in recent years, the area of economic assistance between China and Tunisia has expanded.

Between 2007 and 2009,14 major Chinese companies operating in Tunisia In terms of investment, growth engine and job creation, Ms. Li said that his Government encourages Chinese enterprises to invest in Africa, taking a series of incentives financial, like the creation of a Development Fund for Sino-African expansion of preferential loans for African countries. Tunisia has benefited from the momentum encouragement. Indeed, 14 Chinese companies are major established on the site Tunisian businessman, operating in various fields, such as communication, oil exploration, agriculture, light industry.... 
Chinese investment in Tunisia is expected to grow. Turning to trade between the two countries, the ambassador said that according to Tunisian customs statistics, they amounted to 1.38 billion dinars. The imbalance is obvious, says Ambassador, where the positive steps the Chinese government for businesses Chinese invest in Tunisia, to enrich the variety of products exported from Tunisia to China.

Though it is the smallest country of the Maghreb, but also one of which its economy is the most open worldwide. The country displays a vocation turned towards international trade with Europe and the rest of Africa. The Tunisian economy is more open to the entire region: exports represent $45 \%$ of its GDP, a Real largely due to the reduced size of the domestic market.

Tunisia is one of the EU's most established trading partners in the Mediterranean region with a total value of trade with the EU of $€ 14.7$ billion in 2008. 38.6\% of EU imports from Tunisia are in textiles and clothing, making Tunisia the EU's fifth largest source of imports in this sector. Other significant import sectors are machinery and energy, accounting for, respectively, $18.3 \%$ and $12 \%$ of total EU imports from Tunisia. Major EU exports to Tunisia are textiles $(20.2 \%)$, machinery $(24.1 \%)$ and transport material $(9.4 \%)$.

I can conclude that the trade between Tunisia and China is increasing for imports as for exports. Most of the product mass exchanged increased and some new product emerged which is a good signal showing that we need to think about a direct call from Tunisia ports to China ports and vice-versa.

The aim of my research is developing and analysis of this potential project in order to prove that this new solution is beneficial for both parts.

\section{Project Survey and Market Research}

\subsection{Cost Analysis}

In my research I will make a small case of study will include the most common terms which is the FOB (Freight on board) which is the cost paid by the exporter include load and lash.

The cost analysis will be separated into two different sections: the option of traditional transport shipping passing by transshipment ports TP and the direct shipping DS. The component of each type of shipping is broken down into the elements that incur cost. The demand for particular container shipment drives the cost for each option; that cost in turn is the driving force for the decision to DS or not. As the demand for the specific container shipment the costs for each option are calculated.

Once the costs for each option of shipping have been calculated they are compared to determine at which point it becomes more cost effective to have containers shipped directly DS or by traditional way TS.

> Traditional Shipping Cost:

Table 1. Different shipping rate taken from different careers on December 2010

\begin{tabular}{|c|c|c|c|c|c|c|c|}
\hline POL & POD & $\mathrm{TP}$ & Carrier & \multicolumn{2}{|c|}{ Unit/cost (Dollar) } & Frequency & TT \\
\hline Ningbo & Rades & Via Malta & CMA & $\begin{array}{c}20^{\prime} \\
1870\end{array}$ & $\begin{array}{c}40^{\prime} \\
3540\end{array}$ & $\begin{array}{l}\text { Every } \\
\text { Friday }\end{array}$ & 35 days \\
\hline Xiamen & Rades & Via Barcelona & MSC & 1720 & 3240 & Every Thursday & 25 days \\
\hline Qingdao & Rades & $\begin{array}{c}\text { Via } \\
\text { Barcelona }\end{array}$ & Norasia & 1800 & 3500 & $\begin{array}{c}\text { Every } \\
\text { Wednesday }\end{array}$ & 36 days \\
\hline Guangzhou & Rades & $\begin{array}{c}\text { Via } \\
\text { Shenzhen }\end{array}$ & MSK & 1900 & 3600 & $\begin{array}{l}\text { Every } \\
\text { Tuesday }\end{array}$ & 21 days \\
\hline Ningbo & Rades & $\begin{array}{c}\text { Via } \\
\text { Shenzhen }\end{array}$ & MSK & 1880 & 3540 & $\begin{array}{l}\text { Every } \\
\text { Saturday }\end{array}$ & 21 days \\
\hline Shanghai & Rades & $\begin{array}{l}\text { Via Las } \\
\text { Spezia } \\
\end{array}$ & Evergreen & 1650 & 2800 & $\begin{array}{l}\text { Every } \\
\text { Monday }\end{array}$ & 36 days \\
\hline
\end{tabular}

- POL: Port of loading

- POD: Port of discharging

- TP: transhipment port

- Carrier: CMA-CGM, MSC, MSK (Maersk line), Evergreen

- $\quad$ TT: Transit Time

The shipping rate cost shown in table 4-6 where offered by different career called from China and Tunisia during the last month of year 2010. Usually the rates are changing almost every month depending on the fuel costs and the balance currency. Most of the careers do at least one dearth in one transshipment port during their shipping 
route. (See Figure 4).

Maersk line is the only line making direct call to the Tunisian ports. The company has a good reputation of best quality of service and less transit time but most of the time offering high rates comparing to other shipping companies

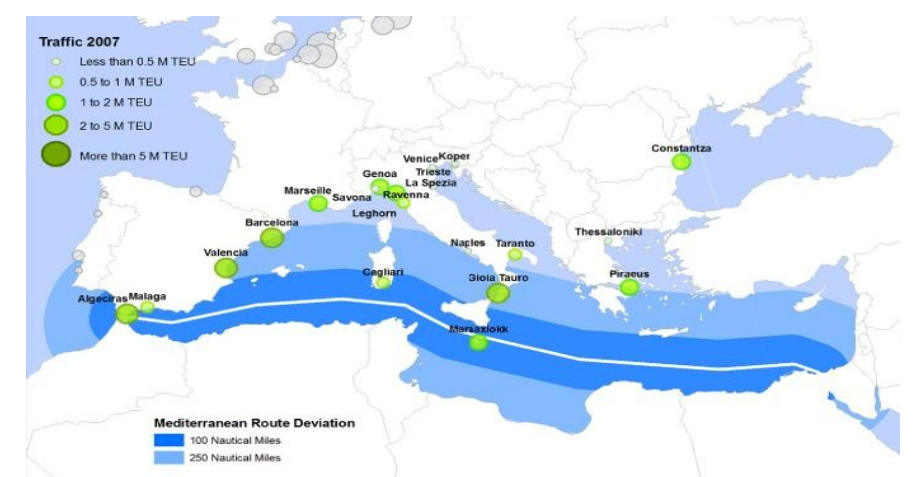

Figure 4. The transhipment in Mediterranean sea (Southern Europe)

> Direct Shipping Cost:

Table 2. Maersk shipping line rates (the only career making direct call to Tunisian Ports) on December 2010

\begin{tabular}{cllcccc}
\hline & & & \multicolumn{2}{c}{ Units } \\
\hline POL & POD & Carrier & 20 & 40 & Frequency & TT \\
Ningbo & Rades & MSK & 2100 & 3850 & Every Friday & 31 days \\
Xiamen & Rades & MSK & 1950 & 3670 & Every & 22 days \\
& & & & & Thursday & 34 days \\
Qingdao & Rades & MSK & 2050 & 3780 & Every Wednesday & 21 days \\
Guangzhou & Rades & MSK & 1900 & 3600 & Every Tuesday & 21 days \\
Ningbo & Rades & MSK & 1880 & 3540 & Every & Saturday \\
& & & & & Every & Monday days \\
Shanghai & Rades & MSK & 2200 & 3800 & & \\
\end{tabular}

- POL: Port of loading

- POD: Port of discharging

- Carrier: MSK (Maersk line)

- TT: Transit Time

The shipping rate cost where offered by Maersk line the only carrier who does direct call to most of the ports all over the world from which Tunisia is as well. Those rates are available until the last month of year 2010. As I said before the company has a good reputation of best quality of service and less transit time but most of the time offering high rates comparing to other shipping companies, which is shown on table 2 . If we compare the 2 tables 1 and 2 we can see that all the rates of Maersk line are higher comparing to what offered from other career. The prices are still reasonable compared to the others and the transit time is much shorter.

Seeing those rates comparing to the option of transshipment doesn't encourage the Chinese shipping company to invest a new line direct calling port of Tunisia. This is normal if you just limit to this condition!

I myself seeing this made me hesitate in the beginning about the idea of emerging a new shipping line calling directly Tunisian port but then seeing other good reasons make me feel more convinced about my thought. After analysing the shipping cost the second point was:

\subsubsection{Chinese Product Ratio Price/Quality}

The economical of China is fast developing, the product exportation quantity are being more and more. The product cost superiority and unceasingly expands the market share make Chinese product winning the prestige. But, the product quality question is also prominent, how to get qualified product by inexpensive price from China?

China wholesalers stand for the manufacturers in China who are busy making quality goods at very pocket friendly prices. Name a commodity or appliance and it is readily available at the lowest possible price in China. And probably this is the reason why many European companies and US rely on China products to cater to their 
customers in their respective countries. These companies are a brand and known for delivering quality products which are produced in China. The increasing export in China depicts the true story of global companies relying on this Asian giant for fastest moving consumer goods, electronic items, electrical appliances and many more products.

China now is the new address where one can get all the products ranging from electronics to electrical and apparel to home furnishings at reasonable prices. Millions of hands are moving fast to produce quality goods in gigantic manufacturing units of China. Global companies including the big names contact China wholesalers for supplies. These companies outsource their manufacturing works to factories in China and take advantage of the cheap labour available only in China. In this way, the companies are earning huge profits while they offer quality products at cost effective prices.

China wholesalers adhere to a time schedule hence they deliver finished goods right on time and at the predetermined appropriate place. When dealing with China manufacturers, one can rest assured that the product would be delivered at his doorstep on right time.

In business time is money and who knows this well than manufacturers in China who work around the clock seven days a week, 365 days a year to beat the deadlines. The quality of the Chinese goods is par excellence and this is evident from the growing popularity of Chinese products in every nook and corner of the globe. Brands of the world rely on China wholesalers and so do the small firms catering to the domestic customers. When shopping for Chinese products, one can utilize a trustworthy trading company. There are many groups who deal with China manufacturers and help companies in the other part of the world get quality Chinese products. Though one can contact suppliers in China directly, a

Trading firm can make it convenient for you to import finished Chinese goods. The trading companies know each and every manufacturer in China hence they lose no time in placing the orders and getting the deliveries.

In Tunisia it used to be that most of the customer they do buy just European or American products because they were afraid of the quality. It was easier for a Tunisian customer to get a flight to Europe and go check and choose a product then shipped to the country. Starting from six years ago the Tunisian customer start to be familiarizing with the Chinese product entering the country from Libya or Algeria. And since that Chinese product was improving quality a lot of product started to be imported from China and in different industries and many new markets for China emerge in Tunisia. So the traffic will become bigger and bigger and it will be multiplied more and more in the future. This trend is the support of the idea project of regular line between Tunisian and Chinese ports, which is beneficial for both sides.

\subsubsection{Tunisia as a Future Transshipment Port}

In the end of 2014, one of the biggest projects in northern Africa will be finished. It is the construction of the first transshipment port in Northern Africa. This project will help Tunisia acquire an infrastructure capacity in order to meet the country external trade progress and participate in transshipment traffic which is rapidly developing in the Mediterranean.

The achievement of this project is integrated within an economic development scope including a modern transport infrastructure and an area of economic and logistics activities aiming at promoting trade activities, industry and services with foreign countries

The Tunisian government launched, with European funds, a study for the construction of a deep-water port dealing with the economic, financial, juridical, technical and environmental framework. This study shows that there is a promising potential market and that Tunisian port site presents the best assets thanks to its proximity to maritime routes and to its physical characteristics.

The site at Enfidha offers multiples advantages to meet Tunisian's international ambitions. It will offer an alternative to the expected saturation of regional-transshipment platforms, while domestically; it will provide international services to the local market.

The creation of a deep-water port is intended to make Tunisia a trading and services providing a modern infrastructure, to expand exports, improve the competitiveness of enterprises and provide direct shipping lines making less transit time (about 15 days) and reduce costs by $15 \%$.

This port will not fail to boost national development strategy of logistics through the creation and development of logistics zones and economic contribution in addition to the first step of creating 8,000 direct and indirect job creation program with over 20000 jobs in the last phase of this project. (Port of Tunisia, Annual Report 2008)

This project encourage all the shipping lines to start thinking of ensuring at least one direct call to Tunisia which 
will be cheaper and faster than passing by the European transshipment ports. And since China is big market for Tunisia and import also many products from almost all the northern African port it will be more convenient, cheaper and faster to establish a regular line to Tunisian ports.

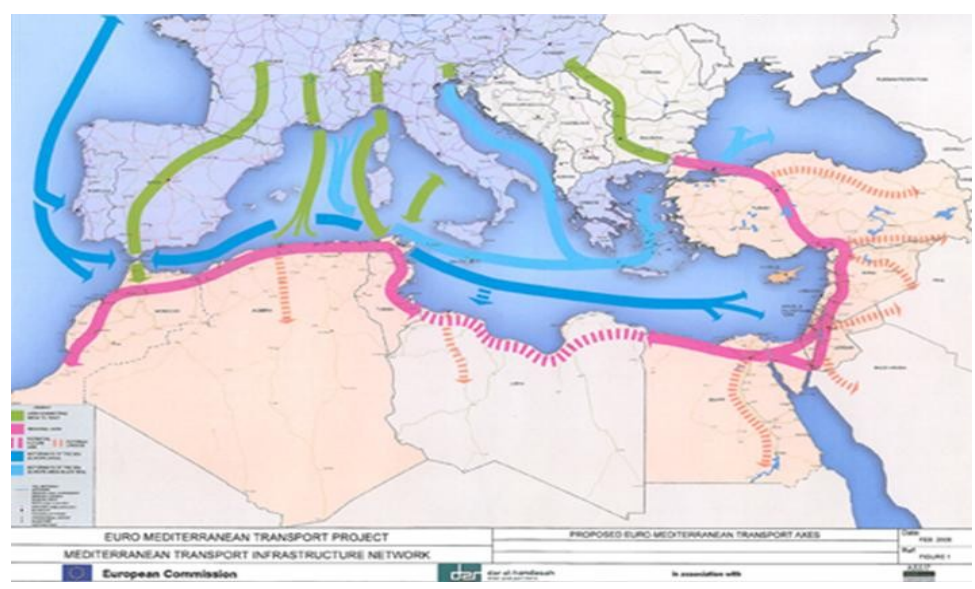

Figure 5. Tunisia a future transhipment port

From figure 5 we can see that Tunisia has a strategic position, situated in the middle of the Mediterranean region, between a European market marked by a rapid economic development and an African continent boosted by its emergent economy and its market of hundreds of millions of inhabitants, the Tunisian port is the most recommended sites for a competitive, reliable and secured transit of goods and ships.

This transshipment port will permit the distribution of the goods for all Mediterranean countries and especially the northern African countries. The goods loaded in Tunisia will be distributed for the local market as to the neighbor countries by land transport, which is very cheap and more convenient for the customers.

\subsubsection{Chinese Diplomacy Challenge North African Revolution}

The protests and revolutions that are sweeping across North Africa since the beginning of 2011 pose a serious test for Chinese diplomacy. The circumstances forced Chinese diplomats to adapt quickly to the unfolding situation, a measure Beijing has been adept at doing elsewhere in Africa when the government in power is threatened or toppled. Yet, the stakes are higher in North Africa than they are in all but a few Sub-Saharan African states. Indeed, China has important commercial and trade ties with all of the North African countries

China seems to have made a successful transition from the previous Tunisian government to the new one. This demonstrates again that China is able to move quickly and usually successfully when regime change occurs in Africa. China is willing to strengthen political exchanges with Tunisia, expand mutual cooperation and enhance coordination on international and regional issues so as to protect the common interests of developing countries.

With the possible exception of Libya, China's relations with the countries of North Africa have not been harmed following the political upheavals. Chinese diplomacy worked quietly behind the scenes to insure that it maintained its interests. China was notably silent in the early stages of all the uprisings and fell back on its traditional public support for stability, national sovereignty and non-interference. At the same time, it supported mild UN Security Council sanctions against Libya and abstained when it could have vetoed strong collective military action favoring rebel forces. China has significant economic and political leverage in North Africa.

\subsubsection{Conclusion}

The total cargo volume between Mainland China and Tunisia is enough for two shipping companies to pay the direct call to Tunisian ports. Currently in the deep- sea liner service for this market, only Maersk Sea land is making direct calls to Tunisia, and several other top container carriers are using independent feeder vessels. The total cargo volume transported by feeder traffic is more than enough for a top carrier to take the direct traffic.

The developing trend of the cargo volume is also promising. China enjoys a phenomenal growth in exports. Instead of purchasing and manufacturing products locally, more and more companies in the African region have since been substituting buying finished goods from China or producing products in China. According to figures recently released by the Far Eastern Freight Conference, trade from Asia to the Africa is booming. During the first quarter of 2009, its westbound traffic increased by a remarkable $32.7 \%$.

In the much larger trade between Asia and northern Africa, more and more shipping companies have started new 
weekly service.

When considering the transit time, we cannot deny that it does take extra time from Mainland China to Tunisia but we have found that using the feeder service sometimes takes longer than transshipping via Tunisia by railway distribution. According to the Tunisian state-owned railway company, the rail distribution can offer a much faster transit time for transshipment to and from several places in Tunisia, partly because the trains are faster than ships, and partly because of the much greater number of feeder vessels calling at Tunis port compared to other Tunisian ports.

The carriers need to consider the transit cost of using intermodal services via Tunisia more thoroughly in more ways. Firstly, statistics show that because of economy of scale, if the vessel has more than a certain volume of import/export traffic, transshipment via the Tunis port is more cost attractive. And the relatively high cost of feeder service from other European ports should make the main- line carriers consider more about calling directly at Tunisia with their deep-sea vessels.

\section{General Conclusion and Recommendations}

I found that a direct call at the Port of Tunisia is worth considering, particularly for the following two kinds of ocean carriers: Those which already have or will have large cargo supply in Greater China Area (including Mainland China, Hong Kong, Macao and Taiwan), and those which already have a strong presence in the African market and plan to extend business even further. From the operation of the Maersk Sea land's direct line between China and China, we can see clearly that paying a direct call to Tunisia should be favoured by the local industry in Tunisia, and it could potentially also benefit from loading additional feeder cargo which was discharged in some European ports.

Some necessary initiatives have been completed for the direct traffic between China and Tunisia. Most ports in China are expanding and they are investing heavily in all-round port construction. The Tunisian ports have achieved much in construction of port's infrastructure and inland distribution network. This will lead to a more efficient handling of goods both in Tunisian and China's harbor. The shipping companies can take advantage of more effective solutions because of the reduced transit time and cost.

The transoceanic market between the Greater China Area and northern Africa is turning a more and more promising market for the shipping companies. The international trade in this market is growing rapidly. Especially, the diplomatic ties and bilateral trade has been developing steadily between China and Tunisia. The reduced custom tariffs, the more transparent and reasonable trade policy, and the improved infrastructure will push the country's import and export forward. I have not found factors that can keep the westbound trade from continuing to increase; and the growing purchasing power in the African region can bring about more transoceanic transport demand.

However, the potentials for a direct traffic between China and Tunisia is rather difficult to achieve right now, unless the goods flow from and to all the European countries can be coordinated to go through the Tunisian port. Of course, the critical Tunisian shippers can also affect the situation. If most importers and exporters turn to prefer using intermodal services via Tunis ports, the direct traffic can be more practical.

It is of great importance for Tunis port to keep its leading position in the African Zone and to coordinate the entire transportation network within the region. In this region, container traffic is increasing and there are good opportunities for expansion for the Tunisian ports. Though the immediate access to the motorway and the railway link could provide swift cargo transports at the port, cooperation in the entire network is still needed for offering the customer better-organized and more efficient "door to door" service.

It is necessary to strengthen the cooperation with Shanghai port. As one respondent said, the cooperation can be performed at different levels. Only the cooperation that has clear and practical objective and mutual effort can work for developing the transoceanic market.

I consider that the Tunisian port should implement a more active marketing policy, especially in cooperating with Chinese ports and the shipping companies in Asia. I have noticed that the port has done a lot in promoting itself, but I do not think it is enough, and the port needs to continue some activities for longer. During the interview of several respondents, I found that they have no or very little, even wrong information about the Tunisian port. They are holding that the price level of the inland rail distribution is still the same to that of several years before. Some respondents of shipping companies talk about their concern about the water depth of the port. More contact and more communication can be really helpful to solve these problems. Information should be better shared with clients and customers alike, by facilitating access to reliable information.

Finally, I want to say that it is very important to understand the Chinese culture in order to have a successful 
business in China. To do business in China is based very much on relationship ("Guanxi" in Chinese). You need to set up good relationships with your customer and related authorities and governments It is of great significance to visit the customer and partner often in order to make the relationship stronger.

\section{References}

Beddow, M. (2003). Enter the dragon, Containerisation International, July issue, P34-37, Informa Group plc., London, 2003.

Beddow, M. (2004). Out on a Limb, Containerisation International, March issue, P93-95, Informa Group plc., France, 2004.

Boyes, J. R. C. (2003). The China Effect, Containerisation International, March issue, p.89-91, Informa Group plc. USA, 2003.

Branch, A. E. (2003). Maritime Economics: Management and Marketing, 2003.

Centre for Maritime Studies, Turku Sjöfartens Analys-institut, Hamburg Inregia AB, and Göteborg TFK Transport forschung GmbH, Sea Transport In The Baltic Sea Region, P39-41, Stockholm, 2004.

Chen, U., \& Caron, J. (2007). Changing Shipping Policy Makes China Access Easier, 2007.

Coyle, J. J., Bardi, E. J. \& Novack, R. A. (2006). Transportation, 2006.

Dekker, N. (2004). Bursting, Containerisation International, November issue, P81-85, Informa Group plc., London, 2004.

Gao, W. (2005). Vice President of China Ocean Shipping (Group) Company, The Impact of China's accession to WTO on Global Trade and Shipping, 2005.

Guangdong Statistical Yearbook, 2006.

Hong Kong trade development council, China's logistics industry presents a golden opportunity, 2007. Retrieved from http://www.tdctrade.com/ imn/imn190/markttrends17.htm

Hong, S. (2005). History and Development of Dalian Port, International Association Cities and Ports, October 2005.

Imms, M., \& Ereaut, G. (2002). An Introduction to Qualitative Market Research, SAGE Publications Ltd, Europe, 2002.

Jonquieres, G. D. (2004). Comparisons between Two Vibrant Centers: Pearl River Delta - Strong on Exports, April 29th, Financial Time World Report, 2004.

Kinnear, T. C., \& Taylor, J. R. (1979). Marketing Research: An applied Approach, McGraw-Hill, and USA, 1979.

Lehmann, D. R. (2002). Market Research and Analysis, Richard D. Irwin, Inc., USA, 2002.

Makhdoom, A. H. (2003). The fundamentals of Ports Management, Makhdoom International Management Center, 2003.

McGregor, R. (2003). China's Economic Showcase is developing fast, April 29th, Financial Time World Report, 2003.

People's Republic of China Yearbook, PRC Yearbook, Beijing, 2008.

Port of Tunisia, Annual Report 2008.

Price Waterhouse, Doing Business in China, U.S.A, 2003.

Rana, N. S. K. (2006). Land Bridge, As an Exponent of Inter-Modality in Trans- Ocean Shipping, Graduate Business School, School of Economics and Commercial law, Tunisia, 2006.

Trujillo, L., \& Nombela, G. (2006). Privatization and Regulation of the Seaport Industry, P9-13, the World Bank Group, 2006.

Wentz, W. B. (2006). Marketing Research: Management, Method, and Cases (2nd edition), Harper \& Row, Publishers, Inc., New York, 2006.

Willmington, R. (2002). Shrewd Investment, Containerization International, Nov 2002.

Woodbridge, C. (2002). Shenzhen Rising, And Containerization International Regional Review: Hong Kong \& Southern China - May 2002, 2002. 
Websites:

WTO_-Trading Into the Future, March 2001 (www.wto.org)

www.cadz.org.cn (China's Economic Development Zone)

www.china.org.cn (China Internet Information Center)

www.coi.gov.cn (China Oceanic Information Network)

www.dzwww.com (Shandong News)

www.eastday.com (Shanghai Daily on the Internet)

www.ft.com (Financial Times)

www.gznet.com (Guangzhou News)

www.marinemoney.com (provider of maritime finance transactional information and maritime company analysis)

www.maritimeeconomics.com (Rotterdam School of Economics, the source of E- journals of Maritime Economics \& Logistics)

www.oocl.com (the shipping company -- "OOCL")

www.peopledaily.com.cn (People's Daily, the most influential and authoritative newspaper in China. It is the same to www.people.com.cn)

www.portshanghai.com.cn (the Port of Shanghai)

www.sina.com.cn (one of the biggest Chinese portal websites)

www.sina.net (the company service website of Sina)

www.Tunisia.tn (the port of Tunisia)

\section{Copyrights}

Copyright for this article is retained by the author(s), with first publication rights granted to the journal.

This is an open-access article distributed under the terms and conditions of the Creative Commons Attribution license (http://creativecommons.org/licenses/by/4.0/). 